\title{
On Some Verses of Li Bo
}

\author{
Paul W. Kroll
}

Horace, in his "Ars Poetica," said poets aut prodesse volunt aut delectare, wish either to be of benefit or to delight. By "be of benefit" he meant "provide with something useful," hence the common translation of prodesse in this context as "instruct" or "edify." So, to edify or to delight. The choice offered has reverberated through centuries in discussions of Western poetry, but poets themselves have usually emphasized Horace's latter term. For instance, Dryden in the seventeenth century: "Delight is the chief if not the only end of poesy; instruction can be admitted but in second place, for poetry only instructs as it delights." Or Frost in the twentieth: "A poem begins in delight and ends in wisdom." On the present occasion, in honor of this volume's dedicatee who loves literature in many languages, I wish to consider briefly some groups of textual shadows and echoes that provoke delight, from both China and the West. In doing so, I model my title after that of the most personal and in many places impetuously outright chapter of Montaigne's Essais, viz. "Sur des vers de Virgile," in which he meditates on passions once known but diminished by age. Although my specific focus will not recall his, the associational freedom and unrepentantly emotional bent of it have something in common. And it is similarities, of various kinds, that are at issue here.

Let us begin with one of the great Tang poet Li Bo's 李白 (701-762) wellknown - if minor-works, a heptametric quatrain, with an AABA rhymescheme, called “At Yellow Crane Tower, Seeing Off Meng Haoran to Guangling” (黃鶴樓㑒孟浩然之廣陵):

故人西辭黃鶴樓 My dear friend bids farewell to the west at Yellow Crane Tower, 煙花三月下揚州 Amid misty blossoms in the third month, goes down to Yangzhou. 孤帆遠影碧空盡 His lone sail's far shadow vanishes in the deep-blue void; 惟見長江天際流Ｎow I see only the Long River flowing to the sky's edge.

Scholars will identify the Yellow Crane Tower as a famous spot in Wuchang 武昌 district, southeastern Hubei, remark the interesting legend surrounding its name, and note that the poem was written in the spring of 738 when the older poet Meng Haoran (689-740), whom Li Bo had met a year earlier, was traveling downstream to Yangzhou (alternatively called Guangling) at the 
mouth of the Yangzi River. Closer readers will comment on the skillful binary alternation of level and deflected tones in the Middle Chinese pronunciation of the important even-numbered words of each line. But all this is scarcely necessary to appreciate, even in translation, the beauty and delicacy of the poem, especially the imagery of the final couplet, as the shadowy speck of the departing friend's sail gradually disappears in the fused hues of water and sky at the distant horizon, leaving to the poet only the river before him, running ever to the unseen sea. ${ }^{1} \mathrm{~A}$ variant version of the poem sees the vanishing sail as a far-off "glint" (ying 映) instead of "shadow" (ying 影); but whether it be a lastglimpsed shadow or a final sun-caught glimmer, either way the effect is supremely touching. The images in that couplet and their implied but unspoken emotions can haunt one, have done so to me since I first read them nearly a lifetime ago.

Does it change one's reaction to them to learn that Li Bo uses very similar wording in another farewell poem? This is one with the generic title of "Seeing Off and Parting" (㑒別), written for an unspecified friend on a now undatable occasion. ${ }^{2}$ The poem is again heptametric (except for a pentametric opening line) but is in eight lines, consisting of two stanzas each of which uses an AABA rhyme-scheme. ${ }^{3}$ The first stanza indicates that the friend is departing from Xunyang 尋陽 in Jiangsu, going up the Yangzi toward Sichuan. The second stanza reads as follows:

送君別有八月秋 I see you off, sir, at a parting in the eighth month, autumn, 颯堸蘆花復益愁 As reed blossoms, blown free in the breeze, again deepen sadness. 雲帆望遠不相見 Your cloudy sail, gazed at afar, is now no longer seen; 日暮長江空自流 At the sun's setting the Long River flows vacantly on its own.

We recognize certain of these elements: the numerical designation of the month, though here it is in autumn instead of springtime; blossoms, though here the last, dying remnants; most of all, the distant sail fading afar and the remorseless river flowing away. The effect is similarly touching, more so if the imagery is encountered for the first time. What underlies the imagery in both cases, what gives that imagery emotional force, is the realization of

1 An elegantly calligraphed scroll of this poem is reproduced as the cover illustration of Reading Medieval Chinese Poetry: Text, Context, and Culture, ed. P. W. Kroll (Leiden: Brill, 2013), one of the numerous books on Chinese literature that Albert Hoffstädt has shepherded for Brill.

2 There are three different poems with this title in Li Bo's collected works. This probably indicates that a more informative title for each was lost somewhere in the transmission process and they were given the generic title by an editor or commentator.

3 Structurally, a rhyme-change marks a new stanza. 
unavoidable temporality, of the friend's departure, of the dimming light, of the running river.

Transience and loss is the human condition. As it is so of everything that is alive or that ever will live. Of all truths, that of impermanence is the most fundamental. As years lengthen and the western horizon draws nearer, this thought lies more steadily before one. One of the essential features of traditional Chinese (and Japanese) culture is the foregrounding of this truth, such that it is an inescapable fact and feeling of life, from earliest youth onward. While there is no lack of celebration of youthful exuberance and the beauty of springtime in Chinese literature, it is the mellowness of experience and the harder beauty of autumn that more often is written of. Half a world away and more than a millennium later, William Hazlitt, near the end of his 1827 essay "On the Feeling of Immortality in Youth," said: "As we grow old, our sense of the value of time becomes vivid. Nothing else, indeed, seems of any consequence. We can never cease wondering that that which has ever been should cease to be." One portion of East Asian literature could be subsumed in these words.

The Japanese phrase mono no aware 物の哀れ, "the pathos of things" or perhaps "sorrow for what exists," is an expression of this conscious heartache for what is (or has been) and of its inevitable passing away. The standard symbolic illustration of the phrase is of cherry-blossoms in their briefly glorious blooming, but the concept embraces the poignant acceptance of all impermanence. An almost exact Western counterpart linguistically of mono no aware is the Latin sunt lacrimae rerum, "there are tears for things," famously occurring in Vergil's description (Aeneid, Book I) of Aeneas's reaction when he sees, on the walls of the temple to Juno that Dido is having built in her newly founded city of Carthage, pictures recounting the defeat of the Trojans. The full verse adds to the three words already quoted: et mentem mortalia tangunt, "and thoughts of mortality touch the heart." In the poem's context the word rerum, for which human tears and death-tinged thoughts arise, refers to the memory of the deeds done and sufferings undergone by the defeated Trojans, which Aeneas realizes are now known even by foreign peoples and even in a far-distant land, and somehow made even sadder for that.

Despite the happenstance of misfortune and the certainty that we all face of ultimate loss, one must continue. There are tasks to do, chosen or put upon one, and forward into the future is the only possible direction. The most acute expression of this in poetry is contained in Milton's concluding lines of Paradise Lost, where he says of Adam and Eve, banished from paradise:

The world was all before them, where to choose Thir place of rest, and Providence thir guide: 
They hand in hand with wandring steps and slow,

Through Eden took thir solitarie way.

There is a sense of the artistically inexorable about this: no other verses than these could have ended the work. The lines compass the end of eternal life and the beginning of human mortality, the desinence of permanent tranquility and the start of patient toil. They also mark the conclusion, finished in 1667, of what many have considered the greatest poem in the English language, which is also the first full-scale and resolute staging in the modern career of blank verse.

The rightness of the lines suggests that they are sui generis, unlike anything else-and perhaps they are unlike anything preceding them in English. But when recently I reread Book II of the Aeneid (mainly because Albert Hoffstädt mentioned that it was his favorite of the epic's twelve books), in which Aeneas recounts at length for Dido the events of the last, fateful day and night at Troy, I found something that intensely reminded me of Milton's lines; or speaking historically, that prefigured them. At the very end of Book II, Aeneas tells how he lost his wife Creusa in the chaos and left behind his house now overrun by the Greeks. With his young son Iulus and his father Anchises who needed bearing on Aeneas's shoulders, he is joined by a small band of other survivors and determines on exile. The final verse of the book reads:

\section{cessi et sublato montis genitore petivi}

That is, "I gave up and, lifting my father, I sought the hills." I find here-in the original Latin, only weakly so in my inadequate English rendering - the same pronouncement as in Milton of resignation that the past is passed and of acceptance that one must now take a new, if unwished for, road. Did Milton model his lines on Vergil's (there are conscious borrowings elsewhere in his poem)? Or was the artist in him prompted to a similar but independent literary solution to the scene he had created? One cannot know for sure. However, as a reader I am sure the atmosphere surrounding both passages is kin and the phrasings have significantly similar weight, yielding altogether the same emotions - and I respond to both in the same full-hearted way.

Upon considering this, a third passage of like feeling and implication comes to mind, from a work that one does not think of in the same category as the work of Vergil or of Milton. It is Hemingway's A Farewell to Arms. Well, of course, suddenly one suspects: the novel's title is itself a negative acknowledgment of the Aeneid's opening phrase, Arma virumque cano, "Arms and the man I sing." But no, Hemingway had no Latin, his novel has no ostensible resemblance to 
Vergil's epic, and in fact the title directly borrows that of a poem by George Peele, a contemporary of Shakespeare. Yet, remembering how the novel ends, with the death in childbirth of the common-law wife of the protagonist Frederic Henry (who is the story's first-person narrator) and destruction of all his careful though meager hopes, I look again at its concluding sentence, a description of bleak affirmation and acceptance: "After a while I went out and left the hospital and walked back to the hotel in the rain." Hemingway is known to have worried over the sentence and to have changed it several times. What he decided on is a baldly plain yet resonant statement, which has been critically celebrated for being shorn of emotion. But lack of explicit emotional statement does not mean the absence of emotion. Quite the contrary (recall, for instance, Li Bo's farewell poems quoted earlier). Frederic's world is now all before him, a different world, totally unlike that previously known and which has now been given up and is forever closed to him. His next steps are, like those of Milton's and Vergil's protagonists, onto an unprepared and unwanted path. The falling rain through which he walks is a lowbrow but aesthetically apt addition to the scene, befitting the intentional understatement of the words. In the end we can embrace only impermanence and frustration, whether it is at the gentlest side farewell to a traveling friend, or most severely the loss of home or exile from paradise, or as here the failure of personal safekeeping when one has already rejected social norms. In all three instances-Vergil, Milton, Hemingway - the concluding sentence emotionally resolves the narrative as though it were dropping down to a minor key, pregnant with a lingering sense of subdued restraint.

It is often said that misfortune and disappointment are necessary teachers and make not only for a better person but also for better writing. In China there is a classic statement about this from the great historian Sima Qian 司馬遷 (ca. 145-ca. 85 BCE). Citing the well-known works of a roster of earlier authors (or supposed authors), he averred:

To be sure, King Wen was made captive but set forth the Book of Changes; Confucius was in dire straits but composed the Spring and Autumn Annals; Qu Yuan was sent away in banishment and only then recited his poem "Encountering Sorrow"; Zuo Qiu lost his sight before there was his Colloquies of the States; Master Sun was punished with amputation of his lower legs and his Methods of Warfare was formulated and put in order; Lü Buwei was exiled to Shu and his Perspectives of Lü was transmitted to the world; Han Fei was incarcerated in Qin and there are his "Difficulties of Persuasion" and "Fervor of the Solitary One"; the three hundred poems of the Odes are, for the most part, compositions made out of the frustrations 
expressed by sages and worthies. The intentions of all of these persons were pent-up and constrained, and they were not able to get through on their desired way, so they recounted happenings of the past, in thought of those to come. And in the end, like Zuo Qiu without his eyes and Master Sun with chopped feet, being useless they retreated and made assessments in their writings, in order to reveal their fervor, thinking to hand down their insubstantial texts as a means to make themselves known.

\section{蓋文王拘而演周易; 仲尼厄而作春秋; 屈原放逐, 乃賦離騷; 左丘失 明, 劂有國語; 孫子臏脚, 兵法修列; 不韋遷蜀, 世傳呂覽; 韓非囚 秦, 說難孤憤; 詩三百篇, 大底聖賢發憤之所爲作也。此人皆意有榃 結, 不得通其道, 故述往事, 思來者。乃如左丘無目, 孫子斷足, 終 不可用, 退而論書策, 以舒其憤, 思垂空文以自見。}

To feel greatly and write worthily in the face of misuse and affliction is both an effect and an inducement. It is not insignificant that Sima Qian could regard himself as a member of the exemplary but discomfited group he describes, having chosen, in order to see to completion his monumental work Shiji 史記 (Records of the Historian), to suffer the disgraceful punishment of castration for an offence committed at court instead of resigning himself to honorable suicide. This paragraph of Sima Qian was much quoted or alluded to by later Chinese writers who felt themselves mistreated or undervalued.

By way of distant association, this brings to mind Boethius's troublingly touching declaration in Book II of his De consolatione philosophiae (written, we remember, while he was imprisoned awaiting execution) that Nam in omni adversitate fortunae infelicissimum est genus infortunii fuisse felicem, "For in all adversity of fortune the most unhappy kind of misfortune is to have once been happy." These painful words of Boethius, written in 523, had a long and curious afterlife in Western literature. For instance, in Canto v of his Inferno, Dante has Francesca begin her telling of the forbidden love between Paolo and her which has consigned them to the restless winds of Hell's second circle with this Italian rendering of the statement: Nessun magior dolore/ che ricordasi del tempo felice/ ne la miseria, "No sorrow is greater than to recall, in misery, the happy times." In English, less than a century later, Chaucer in his Troilus and Criseyde has Pandarus saying to Troilus (Book III), "For of fortunes sharp adversitee/ The worst kynde of infortune is this,/ A man to han ben in prosperitee,/ And it remembren, when it passed is." And in the nineteenth century we find Tennyson, in his "Locksley Hall," avowing: "... this is truth the poet sings,/ That a sorrow's crown of sorrow is remembering happier things." It is not a zealous scholar's wish to quote or comment on Boethius that led to these various 
rephrasings, but rather individual reactions to circumstance and to linguistic context; over the centuries the idea seems to have become almost proverbial.

Indeed there must be truth in something restated by so many different authors (more could be cited than those mentioned in the preceding paragraph) in different times and languages. And memory seems somehow central to it all, for as Bergson suggested, the past must be recalled and used, lest the past cease to exist. Following this thought to its practical destination in literature, Harold Bloom asserted that, "Memory is not only the principal mode of cognition in poetry; it is also pragmatically the major source of inspiration." ${ }^{4}$ Which for me calls up in turn certain favorite lines from Wallace Stevens:

But memory and passion, and with these,

The understanding of heaven would be bliss,

If anything would be bliss. ${ }^{5}$

However, the hard truth of impermanence and the unavoidable sadness produced by time is balanced for us by appreciation of the beauty that exists. It may be that what defines us among other beings in the world, the inherent distinction and even purpose of the human, what we are particularly made for, is to appreciate beauty. The green of summer leaves against a blue sky, fresh bird-calls before the dawn, the desirous nuzzle of dog or cat against a headstroking hand, the face of your child in sleep, Thomas Tallis's unearthly fortypart motet "Spem in Alium" (the nearest we can get to the music of the angels); the list is endless and each of us can add to it as we wish. Stevens again, in one of his essays, said something quite startling and important about our relationship with poetry and the perceived beauty of the natural world:

Poetry is the imagination of life. A poem is a particular of life thought of for so long that one's thought has become an inseparable part of it or a particular of life so intensely felt that the feeling has entered into it.... It is easy to suppose that few people realize on that occasion, which comes to all of us, when we look at the blue sky for the first time, that is to say: not merely see it, but look at it and experience it and for the first time have a sense that we live in the center of a physical poetry, a geography that would be intolerable except for the non-geography that exists

4 In his Ruin the Sacred Truths: Poetry and Belieffrom the Bible to the Present (Cambridge, Mass.: Harvard Univ. Press, 1991).

5 From the poem "Lytton Strachey, Also, Enters into Heaven." 
there-few people realize that they are looking at the world of their own thoughts and the world of their own feelings. ${ }^{6}$

Startling as the claim made in that long final sentence is, and it is the more accurate the more one thinks about it, Stevens's second sentence applies especially — perhaps only — to the kind of cerebral and intensely considered poetry he wrote. It could not be equally applied to traditional Chinese poetry, so much of which is social verse composed more or less on the spot, even if it be the outcome of profound textual learning. The first sentence, however ("Poetry is the imagination of life"), could not be more universally cogent and might even be taken as a gloss on one of Goethe's maxims, namely, Einbildungskraft wird nur durch Kunst, besonders durch Poesie geregelt, "Imagination can only be ordered through art, especially through poetry."

Of course what poetry first and finally depends on is the chief beauty of humanity, that is, language. Language used with grace and love and mastery is what I have tried to foster for nearly fifty years in my scholarly, teaching, and editorial endeavors. Language not only impresses order on our world, as Goethe suggests or, even more basically, as advanced by the Sapir-Whorf hypothesis of how language conditions a particular culture's understanding of the world. It also impresses emotion on the world, allows-indeed encourages-more than brute response. The business, and the pleasure, of studying literature, that is, language's highest reification, begins or should begin with feeling, not with the scientist's desire to know and to analyze, which can itself, I admit, be undeniably satisfying but which for the humanist must occupy second place. How could it be otherwise, when we are dealing with the magic of literally intangible communication that can transmit thoughts not only orally to those here in front of us, but silently even to those separated from us by vast stretches of space and time? As George Steiner said in the opening sentence of his first book, "Literary criticism should arise out of a debt of love."7

From medieval China there is no better statement of what literature is in this temporary world than Wang Xizhi's 王羲之 (303-361) mid-fourth-century "Preface to the Collection [of Poems] from the Lan Precinct-House" ("Lanting ji xu" 蘭亭集序). ${ }^{8}$ One of the most famous prose writings in all of Chinese

6 From "The Figure of the Youth as a Virile Poet," in his The Necessary Angel: Essays on Reality and the Imagination (New York: Vintage Press, 1965).

7 Tolstoy or Dostoevsky: An Essay in the Old Criticism (New Haven: Yale Univ. Press, 1959).

8 "Lanting" is usually misrendered as the pleasant-sounding "Orchid Pavilion." But the word ting 亭 did not yet have, in Wang Xizhi's time, its later sense of a free-standing, unwalled garden structure, here instead referring to the building and grounds of the local government office; and lan 蘭 is here simply a place-name, not a botanical identification. 
literary history, the autograph manuscript of the work is also the single most famous calligraphy text in Chinese history, copies of which are found everywhere today, including in the offices or homes of most scholars of premodern Chinese literature. The occasion for the piece's composition was an open-air gathering of some forty-one men, young and old, of elite status and literary ability, to celebrate the annual springtime "Lustration Ceremony" ( $x i$ 禊). This was also an excuse for an outing to indulge in wine, good cheer, and literary games, during which they were asked to write impromptu poems to celebrate the event. Fifteen of the participants were unable to compose a poem, others composed one or two, and several composed more than that, including Wang Xizhi who composed six and was in fact the host of the event, being the local governor. The poems have been preserved, though they are rarely read now, having long been overshadowed by Wang's essay. This "preface" 9 that Wang wrote afterward for the collected poems provides details of time and place, but then moves into a meditation on larger issues-from differences in personal relationships to questions of life and death, as well as the legacy and influence of literature itself. It touches, we shall see, on most of the themes and topics we have glanced at so far in this essay. In the translation that follows I break the piece into seven short paragraphs, to permit the addition of a running commentary to explain, amplify, or paraphrase certain matters and references.

In the ninth year of the Yonghe era, with the year-cycle at guichou, at the start of springtime's waning, we gathered at the Lan precinct-house in the Shanyin district of Guiji commandery, to carry out the lustration ceremony. A group of worthies all of us, elder and younger assembled together.

\section{永和九年, 歲在癸丑, 暮春之初, 會於會稭山陰之蘭亭, 修偰事也。 羣賢畢至, 少長咸集。}

This was $353 \mathrm{CE}$. The lustration ceremony, meant to purify participants of the unhealthy effluvia accumulating during wintertime, was to be undertaken at riverside, early in the third lunar month. By Wang Xizhi's time it was regularized to take place on the third day of the third month. The Shanyin and Guiji area, in north Zhejiang, was famous for its scenic beauty.

9 The basic meaning of the word $x u$ 序 is "sequence, orderly progression" and hence "to arrange in best order," by medieval times used for a paratext that describes the circumstances of a literary work or collection of works, thus setting it in its proper place. 
In this place are upraised hills and crested ridges, with lush groves and tall bamboo, and what's more-a limpid current purling briskly, with sunlight glinting off it to either bank. This enticed us to engage in floating goblets along the curving river, arranged in our seats according to age and rank. Though there was no repletion of stringed instruments and bamboo pipes, one poem intoned for each goblet set adrift was enough to express with open-hearted joy our deeply held feelings.

此地有崇山峻嶺, 茂林修竹, 又有清流激湍, 映帶左右。引以爲流觞 曲水, 列坐其次。雖無絲竹管弦之盛, 一觞一詠, 亦足以暢敘幽情。

A frequent amusement at parties of the educated elite was the composing of poems while seated at near intervals along a gentle riverside or, more usually, an artificial waterway in a landscape garden, the poem (on a set theme and/or a set meter) to be produced impromptu in the time it took for a goblet of wine floated downstream by your nearest upstream neighbor to reach you. If you were unable to finish a poem in this time you were assessed as penalty a certain measure of wine to drink. Although music of zither and flute was common at festive gatherings, here the recitation of the poems themselves, in the lush local setting, is enough to take the place of music and express the joy of the participants.

This was a day when the sky shone bright and the air was clear and fresh, with a balmy breeze agreeably frisking. Looking up we took in the great breadth of heaven's firmament, looking down perceived the fullness of the world's sundry particulars. Because of this our thoughts ran away with us as we roved our gaze over all, enough to reach the utmost delight of sight and sound-truly something to take pleasure in.

是日也, 天朗氣清, 惠風和暢。仰觀宇宙之大, 俯察品類之盛。所以 遊目騁懷，足以極視聽之娛。信可樂也。

The sunlight, the air, the breeze delight the guests and provoke them to take in both the grand sweep and the precise aspects of, in Stevens's words quoted above, "the physical poetry" in which they find themselves. Their thoughts are unloosed by what they see and hear in this place, a contentment rarely known.

Now, we can say that in people's relations during this life which is no more than a glance up and down, some will take their closest-held thoughts and share them with another inside a single room, while some 
project what is dearest to them in outward exuberance onto what is beyond human form. Though there be a myriad differences between what one chooses to do or not do, and though quietude and restiveness are not the same thing, when facing experiences that gladden the heart, appreciation of them is realized for a while in oneself and so sharp is the satisfaction that one then becomes heedless of time pressing onward.

夫人之相與, 俯仰一世, 或取諸懷抱, 晤言一室之內 ; 或因寄所託, 放浪形骹之外。雖取舍萬殊, 靜躁不同, 當其欣於所遇, 暫得於己, 快然自足, 曾不知老之將至。

This life is but "a glance up and down," just the flicker of an eye. An interesting distinction is made between those who share their thoughts singly with another in a closed room and those who seem to merge themselves with the natural world outside, suggesting a more literal understanding of "introvert" and "extrovert" than the merely psychological. But however one chooses to act, satisfying experiences (like the gathering here on this very day) make time seem to stop, as you lose yourself in the happy moment. Notice that the focus of the preface is beginning to waver, shifting to more general and broader concerns.

But when it happens that such experience is fully spent, our feelings turn along with the occasion while a deep-felt melancholy hangs on. What had previously gladdened one's heart now becomes, in the glance of an eye, but a stale imprint that can do no more than raise a fond memory. Even more is this so when all the changes that go along with a long or short life, at the last, meet their final end. A man of old said, "Life and death are indeed the most important of all!" How can one not be pained by this thought?

及其所之既倦, 情隨事遷, 感慨係之矣。向之所欣, 俯仰之間, 已爲 陳迹, 猶不能不以之興懷。況修短隨化, 終期於盡。古人云, 死生亦 大矣。豈不痛哉。

Such occasions of pure joy do not last, and leave behind a lingering sadness that eventually resolves into "fond memory." This is so for life itself, no matter how long or short, and whatever changes we go through. Say what one will about everything else, it is, after all, the plain, large fact of life and death-as acknowledged long ago by the fictitious Confucius in the fifth chapter of Zhuangzi (though Wang Xizhi here changes the context of the quotation)that looms over all and cannot but cut to the heart. Wang is now fully in 
philosophic mode, though the final comment in this paragraph retains a personal purport.

Whenever I consider the reasons for men of former times being stirred by their emotions, it seems to fit together, all of a piece. And never can I look upon their writings than I sigh with sympathy, though I am helpless to explain it out of my inmost feelings. But I know definitely that saying life and death are just one and the same is groundless blather, and taking Pengzu's longevity and the years of someone who dies young as being equal is specious posing.

每覽昔人興感之由, 若合一契。未嘗不臨文嗟悼, 不能喻之於懷。固 知一死生爲虛誕, 齊彭薚爲安作。

The focus now is on texts and how one reacts to the works of previous generations. Thinking of those who lived before him and who wrote about what they felt, Wang claims to understand them and to feel just as they did, though he cannot put words to why it is. Again, we see, it's a matter of feeling. But what he can say is that the sophistical, linguistic paradoxes of the kind he and his contemporaries know and appreciate from Zhuangzi and spin out in their highbrow discussions in the fashionable jargon of xuanxue 玄學 ("mystical learning”) - for instance, that the longest and the shortest lives are equal in extent and that apparent opposites are really the same-are just fatuous games when placed against the world we actually live in and the decisions we must actually make. This rejection of literati pretentiousness is delivered unequivocally and in thundering fashion. It is the rhetorical high point of the piece, punctuated with the phrase "I know definitely"; there is now for Wang no doubt that the posing of language dilemmas, while entertaining up to a point, is ultimately valueless.

Those who come after will look at us now, just as we now look at those of times past. Most sad it all is! This is why here I note down my contemporaries in order and record what they have set forth today. For even if the world changes and events differ, the way one is moved at heart comes surely to the same thing. And those of aftertimes who consider us-let them be moved by these, our writings.

後之視今, 亦唒今之視昔。悲夫。故列敘時人, 錄其所述。雖世殊時 異, 所以興懷其致一也。後之覽者, 亦將有感於斯文。 
So, it is a continuous thread or, to change the metaphor, an endless cycle, as we are to those who'll live later and will read our writings just as our predecessors seem now to us. The present is the link that holds past and future together. We are here, in this moment, when seen in grand perspective, participants on the largest possible stage, specks in the ever-changing panorama of history. But although everything else may change from one age to the next, human feelings don't change; we can understand each other across time. The poems composed by those gathered here on this day, once preserved as texts (for they were originally composed orally), will carry our thoughts to those we'll never see, who will thereby know and be able to feel something of the persons we once were.

It is a powerful human statement, one that I have read (and taught) many times, and which often brings tears to my eyes. The way in which Wang Xizhi begins with the particulars of the day and gradually expands his view to consider all of time, and these writings in relation to those that have come before and those that will come after, reminds me strangely of the vast enlargement of perspective and knowledge that Cicero effects in his "Somnium Scipionis." There he has a young Scipio Aemilianus in dream visited by his grandfather, Scipio Africanus, who transports his young namesake beyond the confines of earth, from which he is shown the nine circles of the heavens, introduced to the cosmic music of the spheres, and is made to realize how infinitessimally small is our world and the Roman Empire even smaller. But although his fame could merely be known to a small portion of the world, Aemilianus is urged to carry through the noblest of endeavors, to work for the safety of his country, which historically he accomplished with the destruction of the enemy city of Carthage in 146 B CE. "Scipio's Dream" was provided in the fifth century CE with a Neoplatonic commentary by Macrobius, which became a widely circulated school text in the Middle Ages. Although Wang Xizhi's "Lanting xu" acquired no standard commentary, it has remained one of the best-known Chinese texts from the time of its writing up to the present day. The same diminishment of the self and one's world, or perhaps we should say the proper sizing of oneself, as though looking from the wrong end of a telescope, seems evident and salutary in both texts, though their specific backgrounds are as different as can be.

To return finally to Li Bo, I wish now to place beside Wang Xizhi's preface one of the twenty-one prefaces extant in Li Bo's collected works. This is his "Preface [to Poems] for a Banquet with Cousins on a Spring Night in the Garden of Peach Blossoms “ (春夜宴從弟桃花園序). ${ }^{10}$ Scholars have dated the composition variously as from 733,734 , or 739 . But its precise date, like the unknown names of those in attendance, hardly matters for our purposes. The

The title is given variously as “... Garden of Peaches and Plums” (桃李園). 
poems composed by the young clansmen at the feast, which Li Bo refers to flatteringly, have also not been preserved. While the season here is springtime, as in Wang Xizhi's preface, the gathering takes place at night rather than during the day. This is one of several differences within similarity that we shall find in the piece. As we shall also see, the tone is lighter and the progression of thought is arranged in almost reverse order. The preface can be divided into three brief paragraphs, and here again I will insert comments after each paragraph.

Heaven and earth are, to be sure, the travelers' inn of the myriad creatures, and light and shadow are the passing visitors of a hundred ages. And as this floating life is like a dream, just how often can we find happiness? There is good reason that men of old would "take a candle and enjoy the night." Even more is this so, when burgeoning springtime beckons us with scenes of fine mist and the earth itself provides us with artful presentations.

夫天地者, 萬物之逆旅也; 光陰者, 百代之過客也。而浮生若夢, 爲 歡幾何。古人秉燭夜遊, 良有以也。況陽春召我以烟景, 大塊假我以 文章。

We note that Li Bo, unlike Wang Xizhi, begins immediately with the large view, defining space ("heaven and earth") and time ("light and shadow") themselves in parallel syntactic constructions, and explicitly recognizing the mutable nature of life. The phrase "take a candle and enjoy the night" comes from the fifteenth of the so-called "Nineteen Old Poems" from the end of the Han dynasty and refers to the desire of those attending a feast to extend the joyful occasion as long as possible, understandable and very fitting to recall on this present evening. The final sentence, again in balanced, parallel phrasing, suggests that time (spring) and space (the earth, literally "the great glebe" or "greatest mass of soil," an expression from Zhuangzi) induce our enjoyment by means of their natural effects. Most original is Li Bo's use of the term wenzhang as designating earth's inducement. This term, here rendered somewhat literally as "artful presentations" (it might also be "patterned adornment") is in other contexts the standard medieval Chinese term for "literature"; in the social and linguistic situation created by Li Bo it is as though the world itself is offering us its own natural qualities as its version of literature.

Our gathering in this sweet-scented garden of peach blossoms is a happy occasion to celebrate the natural order of relationships. The excellent 
productions of you band of younger men are all like those of Huilian, but the songs I intone would simply embarrass Kangle.

會桃花之芳園, 序天倫之樂事。群季俊秀, 皆爲惠連; 吾人詠歌, 獨 慙康樂。

This festive meeting of elder and younger relations exemplifies the proper order and affinity of senior and junior. An illustration from literary history of a correspondingly admirable relationship is that of the famous poet Xie Lingyun 謝靈運 (385-433), nobly titled Duke of Kangle, and his younger cousin Xie Huilian 謝惠連 (397-433). Just as Lingyun encouraged and appreciated Huilian's compositions, so Li Bo here praises the poems made by his cousins on this evening, while (over-)modestly devaluing his own verses in comparison with those of Xie Lingyun.

Our deep enjoyments do not cease and our lofty talk grows ever more clear. We spread out jeweled mats to sit by the blossoms and send round the winged goblet to drink in the moonlight. If there were no fine compositions, how could we express the elegance we have in our hearts? So, should a poem not be completed in the allotted time, let the penalty in wine be like that assessed at Gold Valley!

幽賞未已, 高談轉清。開瓊筵以坐花, 飛羽觞而醉月。不有佳詠, 何 伸雅懷。如詩不成, 罰依金谷酒數。

As the night wears on (and the wine continues to flow), conversation and expressed feelings seem to take on ever keener attributes. The mats on which they sit are unlikely to have been trimmed with jewels; this is hyperbole. The goblets are "winged" because they are stemless and have two flat handles to hold while drinking, like a Greek kylix; the adjective also suggests the ease with which they are handed round-or perhaps floated on an artificial waterway during poem composition, though that is not specified here. The composition of poems is, Li Bo affirms, an essential feature of such a gathering, and the penalty exacted for failure in this activity has been set equal to that stipulated at the famous banquets held centuries previously at the Gold Valley estate of the wealthy Shi Chong 石崇 (249-300), which was reputedly three dou 斗 of wine. As a measure of capacity, a dou was equivalent to about ten pints. The drinking of thirty pints (fifteen quarts) of wine is an obvious exaggeration for a penalty at a banquet (though most scholars stubbornly support this reading), 
and I think that we must here take the word dou in another of its senses, simply as "a ladleful."

We have noted that Li Bo begins his preface from afar, talking of space and time and of the impermanence they produce. He ends it on the nearest perspective, the wine drunk and poems composed on the present occasion, which we should make the most of just because such occasions are infrequent in the brevity of life; so carpe diem. The movement here, from far to near, is exactly opposite what it was in Wang Xizhi's preface, although the concerns are much alike. Shadows and echoes again, but which can seem new.

Besides the various matters remarked in the running commentary above, something from a more technical side needs to be added about Li Bo's preface. Balancing its light tone and the fairly straightforward diction adopted throughout, Li Bo has structured it in the formal style of parallel prose (piantiwen 駐體 文), primarily made up of syntactically identical, paired clauses in units of four or six words, as typical in that genre. This is evident only slightly in translation, but it is unmistakable in the original Chinese. Another formal grace of the original, which can be recognized only if one reads the text with an awareness of the reconstructed phonic values of Middle Chinese, is that Li Bo alternates nearly every successive pair of phrase-ending words between the binary division of phonetically "level" and "deflected" tones into which words were largely categorized in Middle Chinese and which was employed as a feature of aural artistry in some styles of poetry and in the more formal types of parallel prose. However, that is a particular "delight," to recall Horace, that is demanding of more pointed analysis and requiring a different orientation than we have been pursuing here.

Vita brevis, ars longa. Whether centuries apart or separated by physical distance, the artful manipulation of language bridges gaps and inspires delight. Thinking of my friend Albert Hoffstädt, who delights in literature, I quote once more from Li Bo, these lines which are the penultimate couplet from a long poem remembering an absent friend:11

$$
\begin{array}{ll}
\text { 言亦不可盡 } & \text { As to words, they cannot say it all, } \\
\text { 情亦不可極 } & \text { Nor can feelings be told to their end. }
\end{array}
$$

But the friends we find in and through literature are companions to treasure, beyond words and in the fullness of feelings.

11 The poem, in sixty-three lines, is called "Remembering Our Former Travels, Sent to Aidede-Camp Yuan of Qiaojun” (憶舊遊寄元譙郡參軍). 